\title{
Application of Biotechnological Method to Biodiesel Fuel Production using n-butanol
}

\author{
Irina Kazanceva, Violeta Makarevičienė and Kiril Kazancev
}

Lithuanian University of Agriculture, Lithuania

(received in May, 2011, accepted in June, 2011)

\begin{abstract}
Biodiesel fuel derived from oil (animal or vegetable origin, or used for frying) and alcohol is an alternative to traditional petroleum diesel fuel. The most popular kind of biodiesel fuel is rapeseed oil methylesters. Rapeseed oil butylesters have not been widely analyzed yet.

Transesterification of rapeseed oil was performed using n-butanol and immobilized lipase in the solvent-free medium. The most effective biocatalyst was selected from Novozym 435, Lipozyme TL IM, Lipozyme RM IM, lipase G and lipase F-EC. The most suitable lipase for that process was Lipozyme TL IM. The transesterification reaction was optimized in order to get a highest yield of rapeseed oil butylesters. Optimal conditions (temperature, lipase concentration, rapeseed oil and n-butanol stoichiometric ratio, and reaction duration) of a rapeseed oil butanolysis process were also determined.
\end{abstract}

Key words: vegetable oil, transesterification, lipase, n-butanol, biodiesel fuel.

\section{Introduction}

In recent years consumption of fossil fuel has steadily increased. With a decline in traditional energy stock reserves, the interest in biofuel grows up. Besides, the environment pollution with its greenhouse emissions augments. For that reason in 1997 the Kyoto protocol was signed which obliged the signatories (Lithuania included) to reduce greenhouse gas (carbon dioxide, methane, nitrogen oxide) emissions.

Production and usage of biofuel are encouraged by the law [Law on Biofuel 2004]. Biodiesel fuel is a combustible liquid derived from renewable raw materials. Raw materials for producing biodiesel fuel could be vegetable oil (both edible and non-edible), animal fat, and waste cooking oil (Janulis 2005; Leung et al. 2010; Staniškis 2010). During biodiesel fuel production ordinary fatty raw materials are transesterified by alcohols. Transesterification is divided into: chemical reaction (using alkali or acid catalyst) (Leung et al. 2010) under supercritical conditions (high pressure and temperature) (Balat 2008) and enzymatic reaction. The ferment preparation used in enzymatic transesterification is lipase (Iso et al. 2001, Balat M., Balat $H$ 2010). Figure 1 shows a transesterification reaction using enzyme (lipase).
Biodiesel fuel is alcohol esters of fatty acids $\left(\mathrm{C}_{14}-\mathrm{C}_{22}\right)$. It could be used either as separate fuel or a mixture with fossil fuel (the latter method is more frequent).

The best analyzed transesterification method concerns the use of methanol and ethanol. To decide which alcohol could be used in biodiesel fuel production, it is necessary to know alcohol costs and the properties of both biodiesel produced and acyl acceptor used.

Methanol being the least expensive alcohol is widely used in biodiesel production. However, during enzymatic transestirification, methanol is known to inactivate lipase; in addition, it poorly mixes with oil or fat (Salis et al. 2005).

According to the recently published data, bioethanol may worsen the local air quality and hence it can have a deleterious impact on human health. It also possesses a number of drawbacks, such as low energy density, high vapour pressure and high solubility in water (Black et al. 2010).

Butanol could be produced from the same raw materials as ethanol (biomass fermentation), yet the cost price of biobutanol is calculated to be 5-6\% lower than that of ethanol (Pukalskas et al. 2009).

Besides, n-butanol tolerates humidity better and it is less corrosive than ethanol. In a case of mixtures 
with diesel or petrol, if water penetrates into it nbutanol tends to separate from fuels less than ethanol.

As to the properties of butyl-biodiesel, butyl esters of fatty acids are reported to have cetane numbers comparable to methyl esters of the same fatty acids. Butyl esters are reported to show lower crystallization temperatures than methyl esters (Shinji et al. 2010).

That was the reason to select n-butanol for the study in this research.

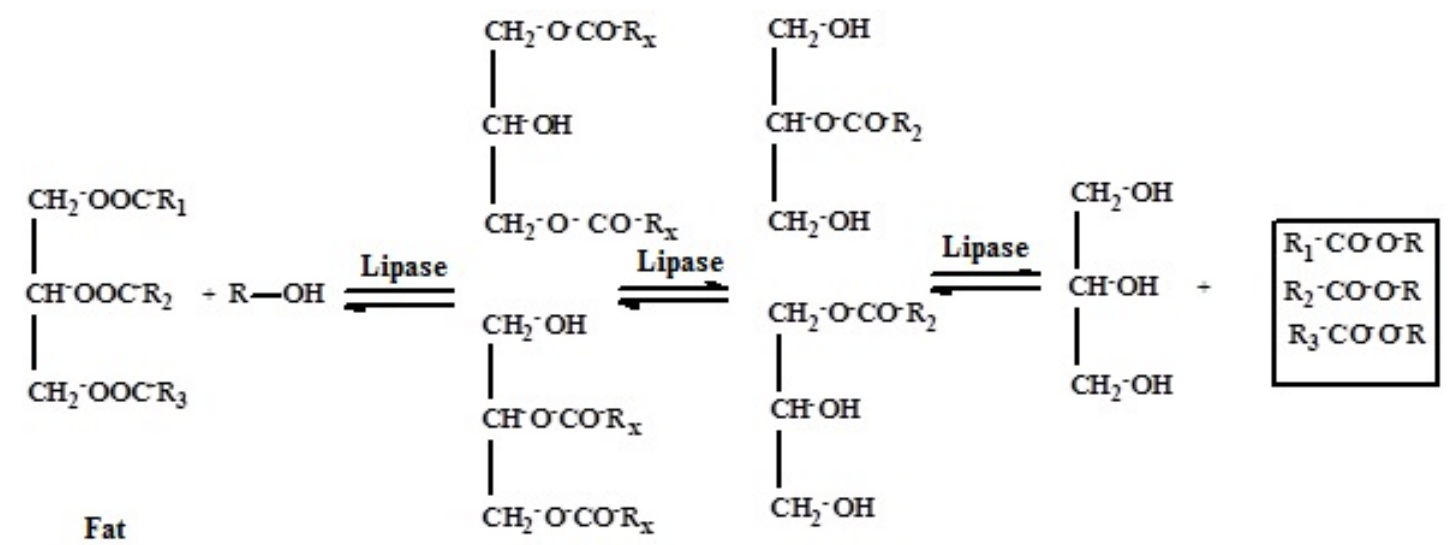

(triglycerides) Alcohol Diglycerides Monoglycerides Glycerol $\quad$ Esters $x=1,2$ or 3

Fig. 1. Synthesis of fatty acid esters during enzymatic transesterification (Balat M., Balat H 2010)

Table 1. Data on biotechnological butylesters synthesis

\begin{tabular}{|c|c|c|c|c|c|}
\hline Oil/fat & Lipase & System & Time, h & The yield, \% & Reference \\
\hline Palm & \multirow{2}{*}{ Pseudomonas cepacia } & \multirow{10}{*}{ Solvent-free } & \multirow{2}{*}{8} & 42 & \multirow{2}{*}{$\begin{array}{l}\text { Abigor et al. } \\
2000\end{array}$} \\
\hline Coconut & & & & 40 & \\
\hline Triolein & Pseudomonas flourescens & & & 90 & Iso et al. 2001 \\
\hline \multirow{3}{*}{ Sunflower } & Lipozyme TL IM & & \multirow{5}{*}{24} & 78 & \multirow{3}{*}{$\begin{array}{c}\text { Deng et al. } \\
2005\end{array}$} \\
\hline & Novozym 435 & & & 54 & \\
\hline & Lipozyme RM IM & & & 60 & \\
\hline Triolein & Pseudomonas cepacia & & & 98 & Salis et al. 2005 \\
\hline Soybean & Lipozyme TL IM & & & 91 & Xu et al. 2004 \\
\hline \multirow{2}{*}{ Sunflower } & \multirow{2}{*}{ Lipozyme RM IM } & & & 65 & \multirow{2}{*}{$\begin{array}{l}\text { Dossat et al. } \\
2002\end{array}$} \\
\hline & & & & 95 & \\
\hline Cotton seed & Novozym 435 & Solvent-free & 7 & 81 & $\begin{array}{l}\text { Köse et al. } \\
2002\end{array}$ \\
\hline \multirow{5}{*}{ Oleic acid } & Lipozyme RM IM & $\begin{array}{c}\text { Diethyl ether } \\
\text { and ethanol }\end{array}$ & 12 & 98 & $\begin{array}{c}\text { Linko et al. } \\
1998 \\
\end{array}$ \\
\hline & Candida rugosa & \multirow{4}{*}{ Solvent-free } & \multirow{4}{*}{30} & 90 & \multirow{4}{*}{$\begin{array}{c}\text { Linko et al. } \\
1995\end{array}$} \\
\hline & Chromabacterium viscosum & & & 95 & \\
\hline & Rhizomucor miehei & & & 98 & \\
\hline & Pseudomonas fluorescens & & & 90 & \\
\hline
\end{tabular}

The synthesis of butylesters has not been completely analyzed. The data on enzymatic butylester production collected by the authors are presented in Table 1.

According to the data presented in Table 1, a highest butylester yield is reached either due to the solvent, or per long synthesis time. It is obvious there is no information on the rapeseed oil butylesters synthesis.

The aim of this work is to study the process of enzymatic butanolysis of rapeseed oil in the solventfree medium.

\section{Materials and methods}

Enzymes: Lipozyme TL IM - lipase from Thermomyces lanuginosa, immobilized on granulated silica (Novo Nordisk, Denmark), Lipozyme RM IM lipase from Rhizomucor miehei, immobilized on macroporous anion exchange resin, (Novo Nordisk, Denmark), Novozym 435 - lipase from Candida antarctica, immobilized on macroporous acrylic resin, (Novo Nordisk, Denmark); Lipase F-EC - lipase from Rhizopus oryzae, immobilized on dextrin (Musster, Germany), lipase G „Amano“ 50 from Penicillium camembertii (Amano Enzyme, Japan).

n-Butanol $(99.5 \%)$ was produced by Chempur.

Butyl oleate (75\%) produced by Sigma Aldrich, fatty 
acids monoglycerides - Palsgaard®0093 pellets. Rapeseed oil methyl esters produced by JSC "Mestilla". Rapeseed oil was purchased from a local distributor. Standards for gas chromatography were of an analytical grade.

Synthesis of rapeseed oil n-butylesters. Synthesis of butyl esters was carried out in a conical flask connected with a condenser, by means of magnetic stirring of $200 \mathrm{rpm}$. The temperature was controlled by a thermocouple. The required rapeseed oil content was inserted into a conical flask and heated to the proper temperature. Then lipase and n-butanol were added. After the transesterification process lipase was separated by filtration and the remaining mixture was washed with acidified water, dried and analyzed by both thin-layer and gas chromatography.

Thin layer chromatography (TLC) method. Chromatographic analysis was carried out by TLC on silicagel G-25 plates impregnated with boric acid. The system of solvents used for elution included a light fraction of petrol ether/diethyl ether/acetic acid (70:30:1) (Surinènaitè 2001). Chromatograms were developed with iodine vapour. Rapeseed oil, rapeseed oil methylesters, butyl oleate (75\%) and monoglycerides were used as control samples.

Produced rapeseed oil butylesters were also analyzed applying a gas chromatography method (gas chromatograph Perkin Elmer Clarus 500), according to the standard LST EN 14105. Conditions of the analysis of the partial glycerides content were: capillary column Restec MXT Biodiesel TG (14 m $0.53 \mathrm{~mm}-0.16 \mu \mathrm{m})$, initial temperature $-50{ }^{\circ} \mathrm{C}$ which was suspended for $1 \mathrm{~min}$. Then the temperature was raised by $15{ }^{\circ} \mathrm{C} 1 \mathrm{~min}^{-1}$ to $180{ }^{\circ} \mathrm{C}$. The temperature was increased by $7{ }^{\circ} \mathrm{C} \mathrm{min} .^{-1}$ to $230{ }^{\circ} \mathrm{C}$ and by $30{ }^{\circ} \mathrm{C} \mathrm{min} .{ }^{-1}$ to $370{ }^{\circ} \mathrm{C}$ and kept for $5 \mathrm{~min}$. The temperature of a detector was $380{ }^{\circ} \mathrm{C}$. The carrier gas flow was $4 \mathrm{~mL} \mathrm{~min} .^{-1}$

Transesterification yield was calculated from the partial glycerides content (Hödl et al. 1994).

\section{Results and discussion}

\subsection{Screening of lipases}

Five different immobilized lipases (see the section "Materials and methods") were tested for effectiveness in the rapeseed oil butanolysis process. Conditions of that study were: $5 \%$ (of the oil weight) of lipase, the oil and n-butanol molar ratio $1: 3$, the reaction duration - 4 hours and the temperature - 50 ${ }^{\circ} \mathrm{C}$.

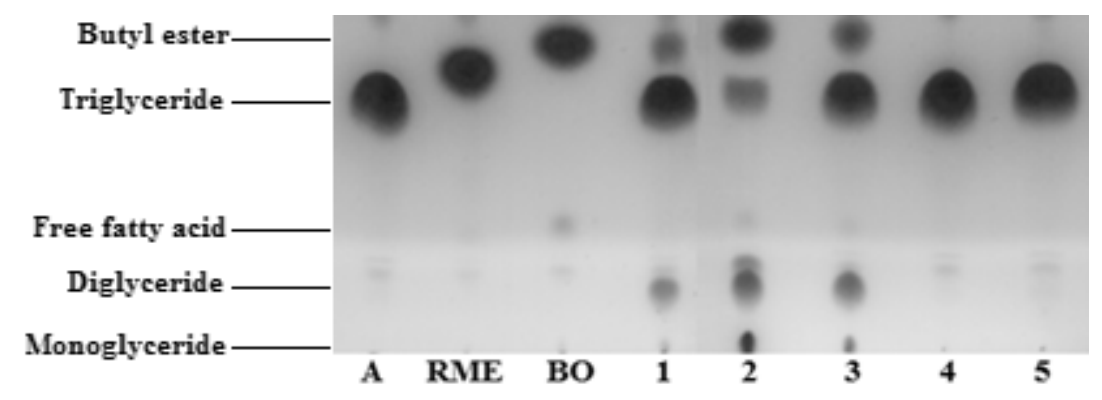

Fig. 2. Effectiveness of lipase in rapeseed oil butylesters production: A - rapeseed oil, RME - rapeseed oil methylesters, BO-butyl oleate, 1 - Novozym 435, 2 - Lipozyme TL IM, 3-Lipozyme RM IM, 4-lipase G "Amano" and 5 - lipase F-EC

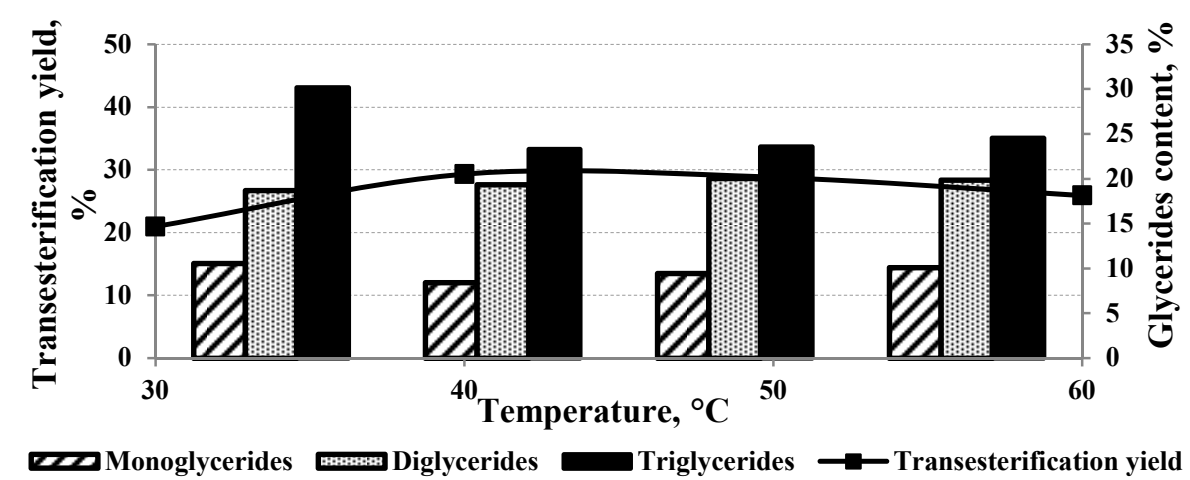

Fig. 3. Effect of the temperature on transesterification yield. Conditions of butylesters synthesis: $5 \%$ (of the oil amount) of lipase Lipozyme TL IM, the molar ratio of oil and n-butanol 1:1.5, duration of the reaction - 4 $h$

Results of thin-layer chromatography (Fig. 2) showed that the use of lipases G "Amano" and F-EC as a biocatalyst resulted in the lowest rapeseed oil butylesters (RBE) yield. Use of lipases Novozym 435 and Lipozyme RM IM led to a higher RBE content, but some rapeseed oil remained unesterified. Only Lipozyme TL IM gave the highest rapeseed oil butylesters yield and the lowest residual rapeseed oil 
content. Therefore, for further experiments ferment preparation Lipozyme TL IM was selected.

\subsection{Effect of the temperature on transesterification yield}

Lipase being a protein decomposes at high temperatures, therefore their range from $30{ }^{\circ} \mathrm{C}$ to 60 ${ }^{\circ} \mathrm{C}$ was selected for the study. The results are presented in Figure 3.

According to demonstrated results, when the temperature was increasing to $40{ }^{\circ} \mathrm{C}$, the content of partial glycerides (triglycerides and monoglycerides) and the transesterification yield grew up. Meanwhile the concentration of diglycerides increased because of splitting of molecules of both monoglycerides and triglycerides. The further rise of the temperature led to a decrease in ester formation (transesterification yield was reduced)

In the light of those results, the optimal temperature of rapeseed oil butanolysis, using lipase Lipozyme TL IM, in the solvent-free medium was determined to be $40{ }^{\circ} \mathrm{C}$.

\subsection{Effect of the stoichiometric ratio of rapeseed oil and n-butanol}

An impact of the rapeseed oil and n-butanol molar ratio on RBE formation was studied (Fig. 4). The following oil and alcohol molar ratios were analyzed: 1:1, 1:1.5, 1:2, 1:3, 1:4, 1:5, 1:6 and 1:7. The synthesis was carried out under the following conditions: $5 \%$ (from oil weight) of lipase Lipozyme TL IM, $40{ }^{\circ} \mathrm{C}$ temperature and 4 hours of reaction duration.

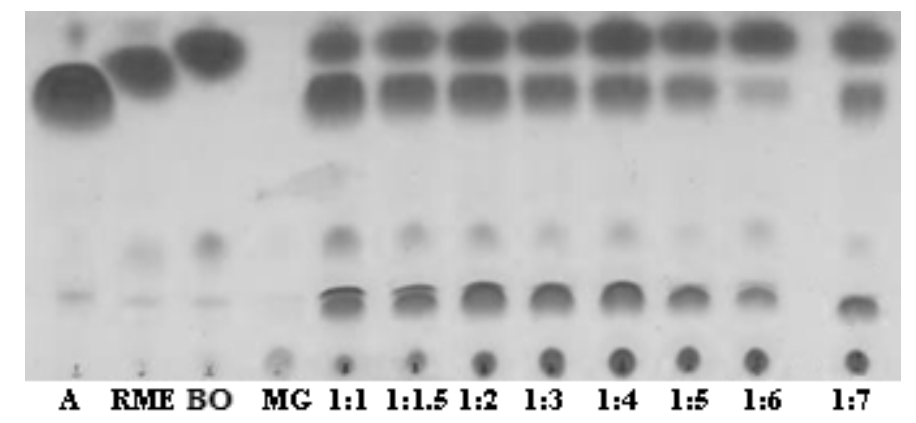

Fig. 4. Effect of oil and n-butanol molar ratio on esters formation, analyzed by thin-layer chromatography: A oil, $R M E$ - rapeseed oil methylesters, $M G$ - monoglycerides, $B O$-butyl oleate

Figure 4 shows that butylesters content increased and rapeseed oil residue decreased, when the molar ratio of rapeseed oil and n-butanol increased to 1:6. But when the stoichiometric ratio was 1:7, the oil content in a reaction product decreased again. In addition, the content of partial glycerides of samples with molar ratios 1:2, 1:4 and 1:6 were determined by gas chromatography and the transesterification yield was calculated from the results of partial glycerides analysis (Fig. 5). These stoichiometric ratios were chosen according to the results of thin-layer chromatography. In these cases the spots of rapeseed oil butylesters were larger than other ones.

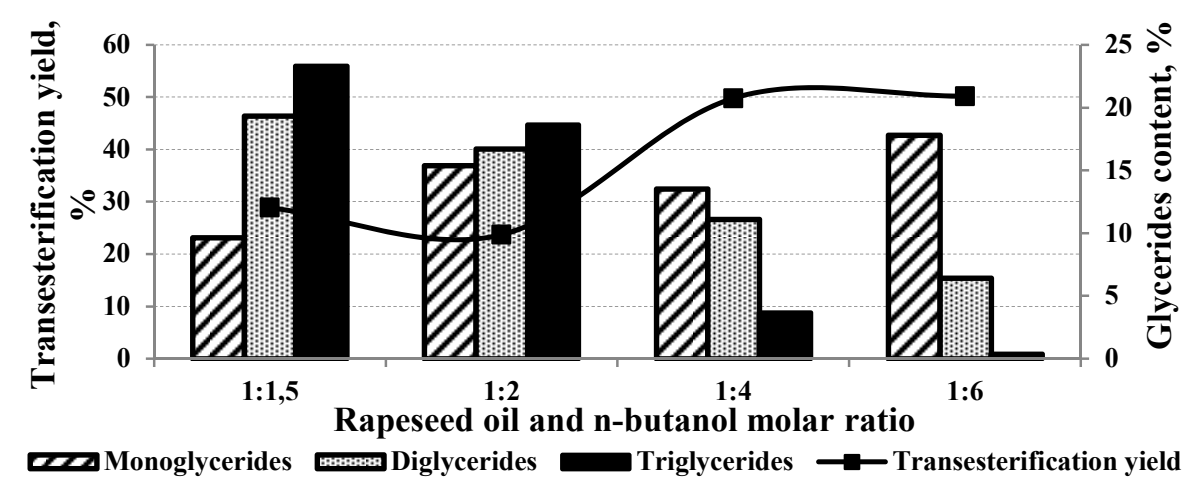

Fig. 5. Effect of the oil and n-butanol stoichiometric ratio on transesterification yield

Figure 5 confirmed the last results of thin layer chromatography. We can see that the highest transesterification yield was obtained by using the 1:6 n-butanol and oil molar ratio. The content of di- and tri-glycerides decreased increasing the alcohol and oil molar ratio.

It can be concluded that the optimal molar ratio of rapeseed oil and n-butanol for enzymatic rapeseed oil transesterification with n-butanol is 1:6. 


\subsection{Determination of optimal concentration of lipase and reaction duration}

The influence of lipase concentration of RBE yield was also analyzed. In experimentation the mixtures with Lipozyme TL IM of the following amount :3\%, $5 \%, 7 \%, 10 \%, 13 \%, 15 \%$ and $17 \%$ from oil weight were used.. The synthesis was carried out in 4 hours and at $40{ }^{\circ} \mathrm{C}$ temperature, the molar ratio of oil and n-butanol was 1:6.

Synthesized samples were analyzed by thin-layer chromatography (Fig. 6). Results have shown that with an increase in lipase concentration, the oil amount decreased and the ester content increased. To qualify results the samples were analyzed by gas chromatography (Fig. 7).

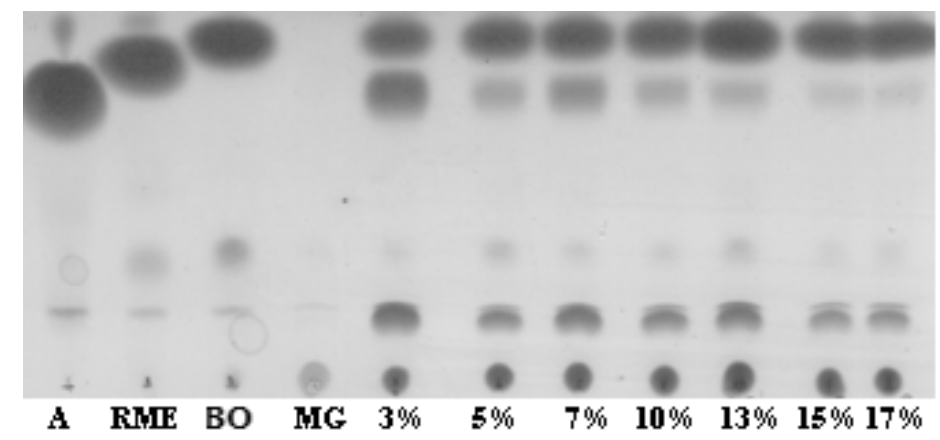

Fig. 6.

Effect of the lipase amount on butylester yield: A - rapeseed oil, RME - rapeseed oil methylesters, BO butyl oleate, $M G$ - monoglycerides

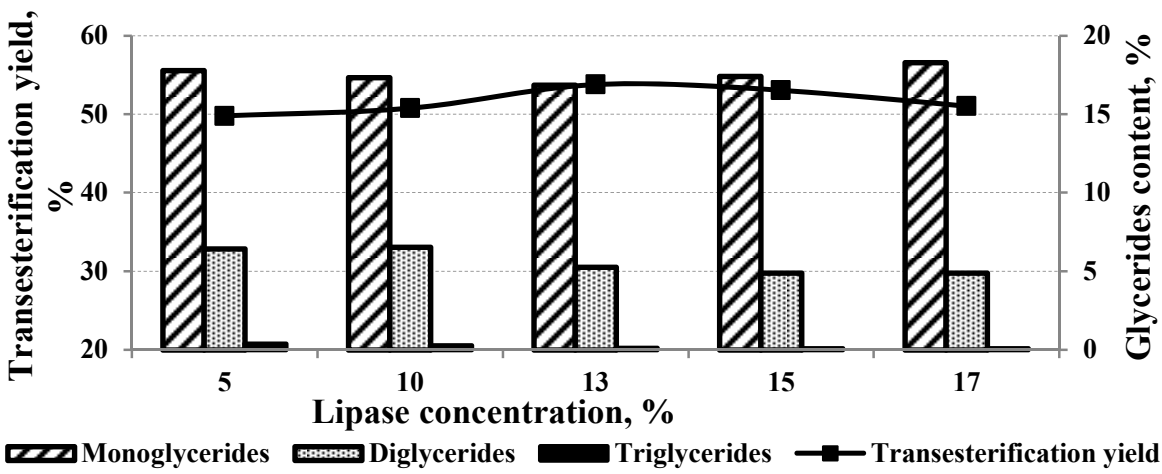

Fig. $7 . \quad$ Effect of lipase concentration on transesterification yield

Figure 7 shows that by increasing the lipase concentration, the tri- and di-glycerides content decreased. The content of monoglycerides as well as transesterification yield increased as concentration of enzyme increased to $13 \%$, and then by further increasing lipase concentration the yield of butylesters decreased (Fig. 6). Consequently, the optimal amount of enzyme for the synthesis of butylesters is $13 \%$.
Additionally, the duration of a butanolysis process was analyzed. The conditions of synthesis were the following: $13 \%$ (from oil weight) of lipase, the oil and n-butanol molar ratio 1:6, the temperature of $40{ }^{\circ} \mathrm{C}$. Dependence of butylesters yield on the process duration was observed for a certain period of time. Results are presented in Figure 8.

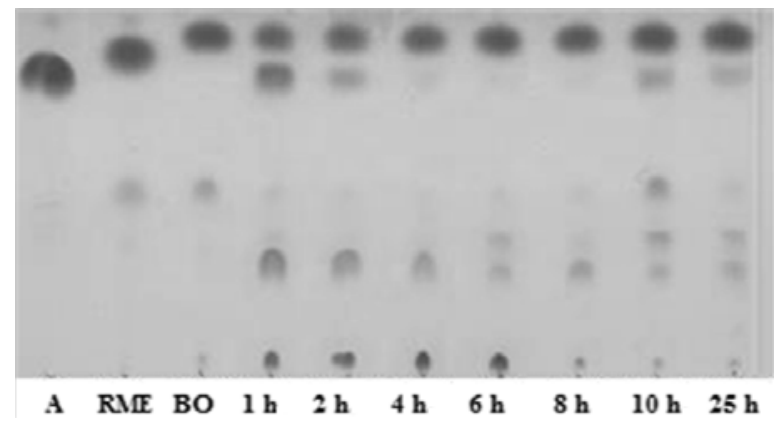

Fig. 8. Dependence of rapeseed oil butylesters yield on process duration: A - rapeseed oil, RME - rapeseed oil methylesters, $\mathrm{BO}$ - butyl oleate 
Thin-layer chromatogram showed that after 4 hours of synthesis the concentration of oil decreased, compared to the earlier (after 1 and 2 hours) measurements. After 6 hours only rapeseed oil traces were seen. When the expiration time was longer than 8 hours $(10$ and $25 \mathrm{~h}$ ), a higher triglycerides content as a result of reversible esterification of formed free fatty acids with glycerol was observed.

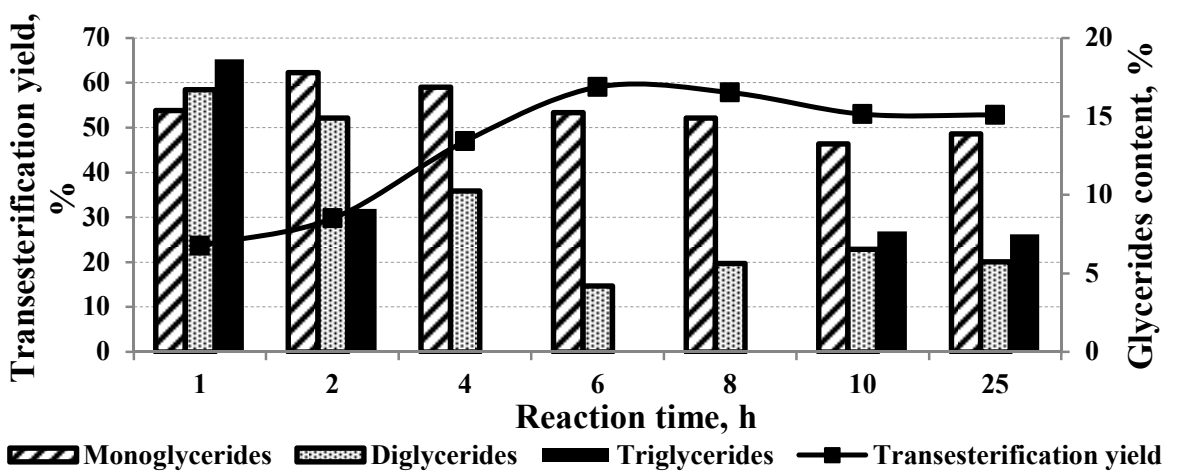

Fig. 9. Effect of reaction duration on the butanolysis process

Furthermore, the partial glycerides content and transesterification yield of products obtained in this experiment are presented in Figure 9. It can be seen that the results are similar to those presented in a thinlayer chromatogram. If the reaction takes more than $10 \mathrm{~h}$, triglycerides are again formed from molecules of mono- and di-glycerides, because a transesterification reaction is reversible.

After $6 \mathrm{~h}$ of reaction the transesterification yield is only about $60 \%$. This product does not meet the requirements of standard LST EN 14214 for both the ester content (it must be no less than $96.5 \%$ ) and the partial glycerides content (it has to be less than $0.8 \%$ of monoglycerides and $0.2 \%$ of mono- and diglycerides). To achieve such ester content it is necessary to carry out additional experiments. The higher transesterification yield could be achieved applying a two stage transesterification process. Such process is usually used in biodiesel fuel production applying chemical catalysis.

\section{Conclusions}

1. The most effective lipase for rapeseed oil butylesters synthesis is Lipozyme TL IM. Other analyzed lipases according to their productivity are of the following order: Lipozyme RM IM, Novozym 435, F-EC and lipase G “Amano".

2. The optimal conditions of rapeseed oil butylesters synthesis are: temperature $-40{ }^{\circ} \mathrm{C}$, duration $-6 \mathrm{~h}$, oil and n-butanol molar ratio $1: 6$, Lipozyme TL IM concentration $-13 \%$ of the oil content.

3. Transesterification yield of butylesters produced under the above given conditions is about $60 \%$. It is evident that such yield is too low and it is to be increased. One of the possibilities is application of n-butanol in the second stage of transesterification. It is necessary to study all possible ways of increasing transesterification yield. One of the possibilities is to apply the second stage of transesterification with nbutanol.

\section{References}

ABIGOR, R.D., UAUDIA, P.O., FOGLIA, T.A., HAAS, M.J., JONES, K.C., OKPEFA, E., OBIBUZOR, J.U., BAFOR, M.E. Lipase-Catalysed Production of Biodiesel Fuel from Some Nigerian Lauric Oils. Biochemical Society Transactions, 2000, Vol. 28, No. 6, pp. 979-981.

BALAT, M. Biodiesel Fuel Production From Vegetable Oils via Supercritical Ethanol Transesterification. Energy Source Part A, 2008, 30, pp. 429-440.

BALAT, M., BALAT H. Progress in Biodiesel Processing. Applied Energy, 2010, Vol. 87, pp. 1815-1835.

BLACK G., CURRAN H.J., PICHON S., SIMMIE J.M., ZHUKOV V. Bio-butanol: Combustion Properties and Detailed Chemical Kinetic Model. Combustion and Flame, 2010, Vol. 157, pp. 363-373

DENG, L., XU, X., HARALDSSON, G. G., TAN, T., WANG, F. Enzymatic Production of Alkyl Esters Through Alcoholysis: a Critical Evaluation of Lipases and Alcohols. JAOCS, 2005, Vol. 82, No. 5, pp. 341-347.

DOSSAT, V., COMBES, D., MARTY, A. Lipasecatalyzed Transesterification of High Oleic Sunflower Oil. Enzyme and Microbial Technology, 2002, Vol. 30, pp.9094.

HÖDL, P. ET AL., Handbook of Analytical Methods for Fatty Acid Methyl Esters Used as Biodiesel Fuel Substitutes; Ed. Fichte, Research Institute for Chemistry and Technology of Petroleum Products, University of Technology, Vienna 1994.

ISO, M., CHEN, B., EGUCHI, M., KUDO, T., SHRESTHA S. Production of Biodiesel Fuel from Triglycerides and Alcohol Using Immobilized Lipase. Journal of Molecular Catalysis B: Enzymatic, 2001, Vol. 16, pp. 53-58.

JANULIS, P., SENDŽIKIENĖ, E., MAKAREVIČIENĖ, V., KAZANCEV, K. Usage of Fatty Waste for Production of Biodiesel. Environmental research, engineering and management, 2005, No.4, pp.101-105.

KÖSE, Ö., TÜTER, M., AKSOY, H.A. Immobilized Candida Antarctica Lipase-catalysed Alcoholysis of Cotton Seed Oil in a Solvent-free Medium. Bioresource Technology, 2002, Vol. 83, pp. 125-129. 
LAW ON BIOFUEL. Žin., 2004, Nr. 28-870 (in Lithuanian).

LEUNG, D.Y.C., WU, X., LEUNG, M.K.H. A Review on Biodiesel Production Using Catalyzed Transesterification. Appl. Energy, 2010, 87, pp. 10831095.

LINKO, Y.-Y., LÄMSÄ, M.,HUHTALA, A., RANTANEN, O. Lipase Biocatalysis in the Production of Esters. JAOCS, 1995, Vol. 72, No. 11, pp. 1293-1299.

LINKO, Y.-Y., LÄMSÄ, M., WU, X., UOSAKAINEN, E., SEPPÄLÄ, J., LINKO, P. Biodegradable Products by Lipase Biocatalysis. Journal of Biotechnology, 1998, pp. 41-50.

LST EN 14105 Fat and oil derivatives - Fatty Acid Methyl Esters (FAME) - Determination of free and total glycerol and mono-, di-, triglyceride contents (Reference method).

LST EN 14214 - Automotive fuels - Fatty acid methyl esters (FAME) for diesel engines - Requirements and test methods.

MONTRIMAITE $\quad$ K., STANIŠKIS J., LAPINSKIENĖ A.M. Potential of Greenhouse Gas Reduction Producing and Using Biodiesel from Fatty Waste. Environmental Research, Engineering and Management, 2010, Vol. 4, No. 54, pp. 34-42.

SHINJI S., YUPING L., TETSU Y., RIE W., MASAAKI K., KOEI K.. Production of Butyl-biodiesel Using Lipase Physically-Adsorbed onto Electrospun Polyacrylonitrile Fibers. Bioresource Technology, 2010, Vol. 101, pp. 7344-7349

SALIS, A., PINNA, M., MONDUZZI, M., SOLINAS, V. Biodiesel Production from Triolein and Short Chain Alcohols Through Biocatalysis. Journal of Biotechnology, 2005, Vol. 119, pp. 291-299.

SURINÉNAITE, B. The Investigation of Pseudomonas mendocina Lipase Specificity and Kinetic Parametrs. Disertation. Vilnius, 2001 (in Lithuanian).

PUKALSKAS S., BOGDANOVIČIUS Z., SENDŽIKIENE E., MAKAREVIČIENE V., JANULIS P. The Mixture of Biobutanol and Petrol for Otto Engines. Transport, 2009, Vol. 24, No. 4, pp. $301-307$

XU, Y., DU, W., ZENG, J., LIU, D. Conversion of Soybean Oil to Biodiesel Fuel Using Lipozyme TL IM in a Solvent-free Medium. Biocatalysis and Biotransformation, 2004, Vol. 22, No. 1, pp.45-48.
Irina Kazanceva - PhD student of the Laboratory Chemical and Biochemical Research for Environmental Technology, Institute of the Environment, Lithuanian University of Agriculture. Main research areas: biotechnology, lipase, biodiesel fuel.

Address: $\quad$ Studentu str. 11, LT-4324 Akademija,

Kaunas, Lithuania

Tel./fax: $\quad+37037752292$

E-mail: $\quad$ irina.sartakova@lzuu.lt

Prof. Dr. Violeta Makarevičienè - head of the Laboratory Chemical and Biochemical Research for Environmental Technology, Institute of Environment, Lithuanian University of Agriculture.

Main research areas: Vegetable oil, biofuel, biolubricant production technology, quality, impact on environmental.

Address: $\quad$ Studentu str. 11, LT-4324 Akademija,

Kaunas, Lithuania

Tel./fax: $\quad$ +370 37752292

E-mail: $\quad$ violeta.makareviciene@1zuu.lt

Dr. Kiril Kazancev - junior research felow of the Laboratory Chemical and Biochemical Research for Environmental Technology, Institute of Environment, Lithuanian University of Agriculture.

Main research areas: Vegetable oil, animal fat, biofuel, quality, impact on environmental.

Address: $\quad$ Studentu str. 11, LT-4324 Akademija,

Tel/fax: $\quad$ Kaunas, Lithuania

E-mail: $\quad$ kiril.kazancev@1zuu.lt 


\title{
Biotechnologinio metodo taikymas biodyzelino gamyboje, naudojant n-butanoli
}

\author{
Irina Kazanceva, Violeta Makarevičienė, Kiril Kazancev
}

Lietuvos žemès ūkio universitetas, Lietuva

(gauta 2011 m. gegužès mèn.; atiduota spaudai 2011 m. birželio mèn.)

Biodyzelinas, pagamintas iš riebalų (gyvūninès, augalinės kilmės ar naudoto kepti aliejaus) ir alkoholio, yra tradicinio mineralinio dyzelino alternatyva. Populiariausia biodyzelino rūšis yra rapsų aliejaus riebalų rūgščių metilesteriai. Rapsų aliejaus riebalų rūgščių butilesteriai nėra plačiai ištirti.

Rapsų aliejaus peresterinimas buvo tirtas, naudojant n-butanoli ir imobilizuotą lipazę. Efektyviausias katalizatorius atrinktas iš lipazių: Novozym 435, Lipozyme TL IM, Lipozyme RM $I M, G$ ir F-EC. Geriausia efektyvumą parodè fermentas Lipozyme TL IM. Siekiant gauti aukštesnị butilesteriu kieki, buvo optimizuoti peresterinimo reakcijos parametrai. Nustatytos optimalios peresterinimo n-butanoliu reakcijos sąlygos. 